\title{
The Military Policy of Isaac Komnenos at the time of battle of Petroe (1057)
}

https://doi.org/10.1515/openps-2018-0011

received December 8, 2018; accepted December 12, 2018.

Abstract: Isaac Komnenos (1007-1060) was the son of Manuel Eroticos Komnenos (955/960-c.1020), one of the associates of Basil II. Thanks to his education, Isaac later joined the imperial army (around 1042). He held the post of stratopedarches of the East and the ranks of magistros. At Easter 1057, the delegation of many military commanders presented itself before the emperor. This delegation was led by Isaac, and along with Katakalon Kekaumenos he tried to convince Michael VI to give them both the title of proedros, but the new emperor rejected their demands. They did not receive the money they counted on the part of the emperor, and he insulted them. This, in turn, became the causative factor of the rebellion, which culminated at the battle of Petroe. The attitudes and actions of Isaac Komnenos at the beginning of the rebellion cannot be unequivocally assessed. It is also difficult to say that it was his skills that were decisive for the success during the battle of Petroe, since he had a moment of breakdown, during which he wanted to leave his army and hide behind the walls of nearby Nicaea. He had a cunctator attitude and faith in the good omens. These qualities also do not reflect well on him.

Keywords: Byzantium; Isaac I Komnenos; Battle at Hades; Constantinople; Michael VI Bringas.

\section{Introduction}

The eleventh century in the history of Byzantium was a period of the greatest triumphs of this Empire's rulers, as well as a violent collapse of state structures, which followed the end of the Macedonian dynasty. This imperial family, whose most prominent representative was Basil II Bulgarslayer (976-1025), led to a balance in political

*Corresponding author: Marcin Böhm, Institute of History, University of Opole, 45-040 Opole,Poland, E-mail: mabohm@wp.pl competition between the court of Constantinople, who was supported by the aristocracy settled in the capital, and the army in which the group of magnates, most of Asia Minor origin, carried out their interests and ambitions. When there were no direct followers of Basil II, both political parties turned against each other and it seemed that the election of the Michael VI Bringas (10561057), supported by the imperial eunuchs, would give power to the Constantinopolitan nobles for good. It was a wrong assumption. In the camp of the military party, a new leader of this milieu, Isaac Komnenos (1007-1060), emerged (Mokhov 2012, 120: 52-53).

Isaac was the son of Manuel Eroticos Komnenos (955/960-c.1020), one of the associates of Basil II (Mokhov 2012, 120:53). At the end of his life, Manuel became ill and, expecting his death, he commanded his sons to protect of this Emperor. The latter took great care of their education by placing them in the Monastery of the Stoudios, where they learned military crafts and were brought up in the virtue of faith (Nicephore Bryennios Histoire 1975, I, 1: 74-77,Varzos 1984, v. A:39). Thanks to his education, Isaac later joined the imperial army (around 1042), where he quickly advanced. He held the post of stratopedarches of the East and the ranks of magistros (Ioannis Skylitzae 1973, 1:479). Isaac was dismissed from his position by Empress Theodora in 1054 and replaced by her eunuch confidant, the proedros Theodore(Ioannis Skylitzae 1973, 1:479). This was one of the first factors that put our hero in opposition to Constantinople. After the death of Empress Theodora, the last representative of the Macedonian dynasty, Isaac hoped that he would regain his position in the army. At Easter 1057, the delegation of many military commanders presented itself before the emperor. This delegation was led by Isaac and included the magistros Katakalon Kekaumenos, the vestarches Michael Bourtzes, Constantine Doukas and his brother John Doukas. Isaac along with Katakalon Kekaumenos tried to convince Michael VI to give them both the title of proedros, but the new emperor rejected their demands (Ioannis Skylitzae 1973, 2:483, Mokhov 2012, 120: 54, Nezu 2006, 42: 53). In addition, they did not receive the money they counted 
on from the emperor. According to Psellos, the emperor insulted to them, at the beginning of his meeting with military commanders. Then he ordered their leaders Isaac Komnenos and Kekaumenos to move forward, that is, after accusing them of cowardice, corruption and improper command of the defense of Antioch. This Emperor's anger affected Isaac the hardest (Michael Psellos, t. II,1928, VII, 3: 84-85). The dismissive attitude of the emperor towards the Eastern Army commanders did not discourage them from undertaking another attempt. A second delegation this time to the protosynkellos Leo Paraspondylos, was received in a similar manner as the first one. Leo rejected all their demands, and at the same time offended them with his arrogant behavior(Ioannis Skylitzae 1973, 5: 486487, Michael Attaliates 2012,XI,2: 96). This, in turn, became the causative factor of the rebellion, which culminated at time of the battle of Petroe.

\section{Methods}

The basic research method is in the case of this article, a comparative analysis of three source texts describing the policy of Isaac Komnenos at the time of the Battle of Petroe. The first extremely important one is the codex written by Michael Psellos (1017-1078), a man of many talents, a monk, a philosopher, a scholar, a courtier, and above all, an absolutist politician (Hussey 1935, 10: 81-83; Polemis 1965, 58: 73-75; Jurewicz 1984, 72/2: 315322, Domaradzki 2005: 117-138). This work can be divided into two main parts. The first includes Books I through to Book VII paragraph 51 and covers the years 976-1059 (from the ascession of Basil II to the end of the reign of Isaac I Komnenos). And this part of the work will be analyzed here, particularly with the plot of Isaac Komnenos coming to power. Psellos was an eyewitness to the rebellion of Isaac and even served as an envoy to him. After this legation, he switched sides to support the usurper. Therefore, Psellos account, despite the often subjective towards the events described, is of great importance to the understanding of the policy of the first Komnenos on the imperial throne. The second key author is Michael Attaleiates (1022-1080), a pupil and associate of Psellos(Krallis 2012: 15-50, Krallis 2009, 40.2: 35-53; Krallis 2009, 67: 169-190; Krallis 2006: 167-191). At the end of his life, Attaleiates wrote his book entitled The History, as a political and military history of the Byzantine Empire from 1034 to 1079. His work shows us the events of the life of Isaac Komnenos from a completely different perspective than Psellos's account. The final author analyzed is John Skylitzes (1040-1101), a younger colleague of Attaleiates and probably another Psellos student (Seibt 1976, 25:81-85). His major work Synopsis

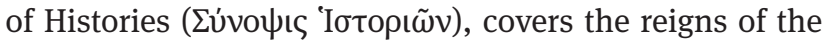
Byzantine emperors from the death of Nikephoros I in 811 to the deposition of Michael VI in 1057. In the context of Isaac's actions and life, Skylitzes draws his knowledge from the works of Attaleiates, trying to get his point of view into this account, especially mitigating the position of Emperor Michael VI against Komnenos before usurpation.

The oldest and quite extensive account of Michael Psellos dedicated to the usurpation of Isaac Komnenos, we found in the seventh book of his chronography. This author mentions that after the Emperor's unkind treatment of the commanders, they wanted oppose him. So they made a conspiracy against him, but they had trouble choosing their leader (Michael Psellos, t. II,1928,VII, 4: 85). The conspirators met twice in Gounaria, in Paphlagonia(Asia Minor). The second time they brought together their troops who joined the rebellion. Isaac, whom Psellos calls the Emperor already in the course of his account of the ongoing rebellion, became, according to this author, very careful. He blocked roads leading to the capital; appointed a group of tax collectors, reporting to him; appointed his commanding staff and introduced a new pay for his soldiers; he surrounded himself with the protection of his relatives (Michael Psellos, t. II,1928,VII, 6-9:86-88). At the time, near Emperor Michael, Psellos advised him to meet with the usurper, send him a legation and gain on time, and finally gathered troops from the European part of the country, which were to be strengthened by drafting mercenaries and units of nearby barbarian allies (Michael Psellos, t. II,1928,VII, 10: 88-89). The Emperor dismissed some of his councils, but he began to assemble an army that outnumbered the troops of Komnenos, and at its head, he set the eunuch Theodor, the Domestic of the Schools of the East. The arrival of this force in Asia Minor was overlooked by Psellos. We know from his accounts that both armies set up their camps in a place that this eloquent author did not identify by name. And from the very beginning of their stay, the army of loyalists suffered because of the weaknesses of their commanders. In addition, there was desertion on the usurper's side (Michael Psellos, t. II,1928,VII,11:89).

Attaleiates sees the start of the rebellion somewhat different than Psellos. According to him, the beginning of the rebellion was preceded by the capture of one of the leading conspirators, Bryennios, who took possession of property intended for the payment of soldiers wages. This act led to his capture and blinding by the followers of the reigning Emperor (Michael Attaliates 2012,XI, 3:96). The rebellion was to take place on the equinox of 1057 (8 June) and initially it did not run smoothly. The Soldiers 
from the army of the East in the city of Byzas, remained faithful to the emperor, that is why Komnenos could only count on the support of some of the Anatolian troops. Without wasting time, the Emperor diverted some of the military troops from Europe to Asia Minor, which went to Nicomedia, where they camped, awaiting the usurper's army. However, once they did not encounter the enemy at that location, they headed to Nicaea, according to the imperial order. On the spot, it turned out that the inhabitants of Nicaea gave keys to its gates to Isaac, who, having the city behind his back, could finally move on the enemy(Michael Attaliates 2012,XI, 4:96).

As the beginning of usurpation, John Skylitzes also sees the capture of Bryennios. However, he gives us more details about this situation. Namely, Bryennios was sent earlier to fight with the Turks, and in principle with their leader Samouch. That Turk destroyed the lands of the Empire in the eastern part of Anatolia, along with three thousand of his people. Instead of money to fight the enemy, for which he asked the Emperor, Bryennios was deprived of his position(Ioannis Skylitzae 1973,3:484). Skylitzes mentions that Kekaumenos opted to include Bryennios in the plot because he commanded Macedonian troops. It was also Kekaumenos who suggested the person of Isaac Komnenos to the other conspirators, instead of his own candidacy(Ioannis Skylitzae 1973, 5:487). Bryennios regained his position once again and set out due east in the company of patrician John Opsaras, who was to pay the soldier. As a military leader, Bryennios captures Opsaras on the spot and took gold which belonged to the state. Lykanthes, commander of Pisidia and Lykaonia, upon receiving the news of his actions, attacked the Bryennios camp, at the helm of two military units coming from the Anatolikon theme. They surprised the disobedient commander, who was then handed over to Opsaras and blinded (Ioannis Skylitzae 1973,6:488, Inoue 1993, 272-273). According to Skylitzes's words, upon receiving the message of the capture of this conspirator, Romanos Skleros, Bourtzes, Botaneiates, the sons of Basil Argyros went to Isaac, who was at his family nest - Kastamon in Paphlagonia (Ioannis Skylitzae 1973, 6:488-489). It was these people who encouraged Isaac to act and go to Gounaria, where the whole rebellion began. There, he received a message that Kekaumenos went on to the Emperor's side, which seemed to be a huge blow to the usurpation. This did not really prove to be true, because soon after the meeting with the Emperor and after leaving the capital-Constantinople, Kekaumenos went to his estates located on the road that ran through Nicomedia. There he threatened the imperial courier that he was giving up imperial service like Komnenos was supposed to do. He did it before some of the conspirators could enact their plans, which is why Keukamenos went back on his word, because he had expected to see the beginning of the rebellion coming from Komnenos, who instead remained calm. Kekaumenos did not have any military units under his command at that moment, so his fears about the potential aggression of the reigning Emperor seemed understandable. Fortunately, two units of the Franks and one Ruthuenian were wintering in the area where he was staying. The second leader of the revolt was afraid that the units would capture and hand him over to the ruler. However, that did not happen. He managed to amass 1,000 people from among his neighbors and clients, and later also other notables. The eminent commander also prepared the imperial document, which gave under his command the above-mentioned three units of allies, to which he added two other from Koloneia and Chaldia, at whose helm he was supposed to move on and attack Samouch(Ioannis Skylitzae 1973,7: 490-491). He then instructed the five military units to gather on the plain at Nicopolis. There, through threats, he convinced the leaders of these units to join his side. They had no other choice but to swear allegiance to him. He also called to arms of the officers and men of Sebasteia, Melitene, Tephrike, and the Armenian theme. Kekaumenos brought these people to Komnenos, which significantly strengthened the position of his usurpation. After joining his friend's troops, Isaac placed his wife and movable property under the protection of his brother John, and ordered him to take refuge in Pemolissa Castle, on the bank of the Halys River(Ioannis Skylitzae 1973,7: 491-492). Then he turned to Nicaea. Marching slowly along the way to this city, he crossed the river Sangarios, giving the emperor's faithful troops time to escape. The withdrawal turned into uncontrolled panic. There was a massive desertion of ordinary soldiers in the ranks of the loyalists, and some of the commanders left their positions and went to the Emperor to inform him of Isaac's progress(Ioannis Skylitzae 1973,7: 492). Michael VI, at the news of these events, gathered an army in which distinguished military troops of Macedonians, and those derived from the themes of Anatolikon and Charsianon themes, headed by the aforementioned eunuch Theodor, accompanied by the brother of the wife of Komnenos, Aaron. This army was flipped over to Chrysopolis, and then headed towards Nicomedia. They destroyed the bridge on the Sagarios River, and then the army of loyalists set up camp near Mount Sophon(Ioannis Skylitzae 1973, 8:493). According to Skylitzes, Komnenos was informed by the network of his spies about the actions of Emperor Michael's people. That's why he took Nicaea with just one blow and then 
waited there for the enemy to come. Before the clash, his opponents tried to arrive at a compromise but were unable to convince one another (Ioannis Skylitzae 1973, 9: 494).

All three versions of the events presented above complement one another. Paradoxically, the most details can be found in the work of the latest, written by Skylitzes. However, before we move onto a deeper analysis of the policy adopted by Isaac Komnenos at the beginning of his usurpation, it is worth presenting the course of the battle, which is also described in these three analyzed works. The Battle of Petroe was fought on 20 August 1057(Bonarek 2011: 47-48, Dudek 2009: 51 , Angold 1984: 50, Krsmanović 2001: 210-213, Mochov 2002, 33: 119-120, Mokhov 2012, 120: 55).

We must startagain with the work of Psellos. According to poetic descriptions of this author, the Battle of Petroe was started by the army faithful to the Emperor. Their right wing broke the left wing of Isaac's forces and began to pursue them. The right wing of the usurper's army also escaped. Suddenly, the left flank of Komnenos returned to the fight, and the usurper himself fought a battle with four Varangians (Taǘpúv $\Sigma \kappa \theta \dot{\omega} v$ ) from the imperial troops. Psellos goes on to say that Isaac managed to survive this clash with the Varangians, which he took for a lucky omen. That's why he ordered his soldiers to continue fight to the point of victory, which also happened(Michael Psellos, t. II, 1928, VII, 13:90-91). At the news of this defeat, morale in the camp of Emperor Michael waned. And his warlord himself, eunuch Theodor made secret peace with Isaac, so he lacked the will to continue the fight, at a time when there was nowhere to replenish reserves and recover from the losses suffered at Petroe(Michael Psellos, t. II, Paris, 1928, VII, 14: 91).

Attaleiates sees the battle at Petroe in a somewhat different light. According to him, both sides met ten stades from the city (Nicaea), in a place called Hades or Polemon. The right wing of Komnenos escaped, but the usurper strengthened his left one with the best troops he had. There was a fierce hand-to-hand fight, where Komnenos's supporters started to win. At this sight, the right wing of Isaac's army returned to the fight, which surrounded the imperial army and determined his victory. There was a bloody slaughter of the defeated, many of whom were killed trying to escape. Attaleiates calls this bloodletting of fratricidal life. From the commanders who were supposed to be particularly active on the side of Komnenos, he mentions Nikephoros Botaneiates, who will later win the imperial crown for himself (Michael Attaliates 2012, XI, 5-6: 99-100).

Again, we owe the most comprehensive account of the battle to Skylitzes. The servants of Emperor Michael, the Macedonians, were particularly keen to start the clash with the rebels. They watched the actions of Isaac's people and camped under Petroe near his forces, almost 15 stadia from his camp. This was to provoke Komnenos to act and it succeeded, but not in a way the loyalists had anticipated. Isaac developed the order of the battle, and entrusted the command of the left wing of his army to Kekaumenos, the right wing to Roman Skleros, while he took charge of the center of his forces (Ioannis Skylitzae 1973, 9: 494, Nezu, 2006, 42: 43). The imperial armies also developed their order. The center was taken over by the imperial eunuch Theodor. The right wing was under command of Basil Trachaniotes, who was commanding the Macedonians and left by Aaron, brother-in-law of Isaac, who was accompanied by Lykanthes, Pnyemios, Randolf the Frank, who acted as his sub-commanders. After battle preparations, both forces went into combat. Aaron smashed the wing of Roman Skleros, whom he took alive into captivity in the camp attacked by his men. There he wasted time allowing his people to loot the camp. Seeing this, the usurper considered escaping to hide behind the mighty Nicaea walls. Fortunately for him, in the meantime, Isaac broke the resistance of the troops located before the front of his center, and then he broke into their camp, which he plundered. At this sight, the morale of the faithful troops of the Emperor, including commander Aaron himself, staggered. The prisoners taken in the camp were killed in the fight on this wing(Ioannis Skylitzae 1973, 9: 495). In the final phase of the battle, Randolf the Frank wandered around the field looking for a worthy opponent. In Skylitzes's opinion, he found him in the person of Nikephoros Botaneiates. Botaneiates defeated him and took him prisoner, and then handed over to Isaac Komnenos. Also, according to this author, several people from the Komnenos party and only one commander of his troops, Leo of Antioch, fell during the battle(Ioannis Skylitzae 1973,10: 495-496).

Some auxiliary roles in the description of this battle, as well as the events preceding it, are fulfilled by three historical sources related to Byzantium, written much later (from the 12th century), and thus indirect. The first of these twelfth-century authors is Konstantinos Manasses. According to him, Isaac went to emperor Michael expecting to gain more benefits from him but was he unsuccessful and he was insulted(Constantini Manassis 1996, vol. I, 6266-6270: 339). He became greatly distressed after this encounter and was planning usurpation, so he recruited Konstantinos Doukas and many others, and gathered an army from Asia against the Emperor to remove him from the throne(Constantini Manassis 1996, vol. I, 6270-6276: 339). Manasses also speaks briefly about the clash. Isaac 
won the civil war in battle, or according to another version of this line of work of Manasses, he was offered rule by the chiefs of the empire because of his competence in war and administration(Constantini Manassis 1996, vol. I, 6285a-6285h: 340).At the end of his description of the usurpation, Manasses mentions that a civil war broke out, and Romans were killed by Romans, Isaac won the battle and the older Emperor was unwillingly removed from power(Constantini Manassis 1996, vol. I, 6286-6292a: 340).

John Zonaras does not provide us with too many comprehensive new data, either. In the context of the reasons for the pre-battle rebellions, he says that army commanders rushed to the defense of Katakalon Kekaumenos, during his defense of Antioch, but emperor Michael VI did not spare his tongue against them, nor did he show respect to Isaac Komnenos(Ioannis Zonarae 1897, XVIII, 1: 654). Because Zonaras based his work on the works written by the abovementioned three authors, the further description of the events brings nothing new to our considerations, except that Katakalon Kekaumenos's victory on the left wing in particular implanted boldness in his men, and cast down the spirits of their opponents and persuaded them to flee (Ioannis Zonarae 1897, XVIII, 2: 660).

The last author from this group of indirect sources is Matthew of Eddesa. This Armenian chronicler gives us another interesting description of the beginning of the Komnenos rebellion and the course of the battle. According to his words, Isaac pitched camp by the banks of the Mediterranean, on an Asiatic side and, with great violence, sought the throne of the Byzantine empire. Then Emperor amassed troops from all the lands of the West and transported the entire multitude of them to Chrysopolis. On that day a great and frightful battle occurred, affecting Christians, since both sides struck each other, causing heavy casualties. Then Komnenos advanced, breaking the resistance of the men loyal to the Emperor, resulting in all of fleeing. On that day some 115,000 warring men of the Byzantine troops died. The Usurper Komnenos took captive all the Roman princes and seized control of the Empire.(The Chronik of Matthew of Edessa 1993: 89).

After the remnants of the imperial army withdrew to the capital, Komnenos moved to Nicomedia. In this town he was met by envoys of the Emperor: Konstantinos (Michael) Psellos consul to the Philosophers, Konstantinos Leichoudes and Theodore Alopos. They returned to the Emperor, received another commission and came back again, meeting Komnenos as he advanced on the village of Rheai. The embassy announced that Isaac would be proclaimed emperor and adopted as a son, and they also tried to officially bribe his commanders, with confirmation in imperial letters of the honors granted to them by the usurper. The temptation of the commanders was resisted by Kekaumenos, and Isaac publicly rejected these proposals, but privately he proved to be more open to negotiation. During the course of these negotiations, a riot in favor of Komnenos broke out in Constantinople. Patriarch Michael Keroularios convinced Michael VI to abdicate in Komnenos's favour on 31 August 1057. Komnenos entered capital of Byzantine Empire on 1 September and was crowned emperor(Michael Attaliates 2012, XI, 6-9:100-106, Ioannis Skylitzae 1973, 11-12: 496-500, Michael Psellos, t. II, 1928, VII, 15-42: 91-110; Shepard 1977, 38: 22-30, Bonarek 2011: 48 , Dudek 2009: 51-52, Angold 1984: 50, Krsmanović 2001: 213-231, Varzos 1984, v. A: 42, Mokhov 2012, 120: 55).

\section{Results}

When we are reading our main historical sources depicting the process of the rebellion of Isaac Komnenos and then the battle of Petroe, we can get the impression that the actions of this man were haphazard, and he did not act according to any plan. The people represented by Komnenos were descendants of military aristocracy, which was formed during the reign of Basil II. The father of our hero, Manuel Eroticos, was the best example of this. For the successors of Basil II, who was an eminent ruler, they were necessary to defend the state's borders against external enemies, as well as suppress rebellions and potential usurpations. The new ruler Michael VI commenced his reign from the elevation, also financial, of many new people, who were raised to higher dignities, and the military party sought a chance to partake in the Emperor's plans. Earlier as a military logothete Michael Bringas was responsible for was the debasement of the Byzantine currency under Konstantinos IX Monomachos (1042-1054), which affected military pay(Treadgold 1997: 597). The commanders gathered around Komnenos and Kekaumenos. They probably hoped that after taking over the imperial power, Michael would look kindly at them and provide the army with the funds to maintain it. Their ambitions were not satisfied, and in addition, the Emperor publicly humiliated them. It happened on the Easter of 1057. This event became, as rightly emphasized by all sources, the immediate cause of the rebellion.

From the very beginning, however, the rebels had trouble finding a leader to lead them. The solution to this problem was supposed to be the veteran general Nikephoros Bryennios, who had earlier unsuccessfully tried to usurp the throne from the Empress Theodora (Kaldellis 2017:215). He joined the conspirators and 
promised to support them, but he moved too quickly into action by imprisoning the treasurer who was responsible for paying out wages to soldiers, when he was sent with his new army to Asia Minor to fight against the Turks. When Bryennios was arrested and lost his sight as a result of blindness, this led to another change of the conspirators' plans. We do not know when the event took place, but it probably happened in the spring, perhaps at the end of May 1057.

As we remember, Kekaumenos opted for involving Bryennios in the plot. This commander also rejected his candidacy in favor of Isaac Komnenos. Kekaumenos was Isaac's strategic partner, on his way to the throne. In spite of problems with effective communication at the beginning of the rebellion (remember that Kekaumenos acted faster against Emperor Michael VI, ahead of Komnenos), due to the size of Asia Minor, he managed later to collect, under his command, elite infantry and cavalry troops, which included the Armenians, Ruthenians, and finally Latins. After all, he went as far as to falsify imperial documents to take command of a part of the troops from Anatolia, which testifies to the determination of the conspirators. It was also Kekaumenos, who was instrumental to the outcome of the clash at Petroe, breaking the loyalist wing with his troops. So Michael Bringas was wrong about him the most, accusing him earlier of ineptitude, corruption, and humiliating him in the end.

The beginning of the rebellion and the battle of Petroe are almost three months apart. Isaac used this time to collect and enroll his allied troops, initially among friends and relatives, to whom he later added the contingent of Kekaumenos. How large could his rebel army be? Probably this number would not surpass 3,000-5,000 infantry and riders(Nezu 2006, 42: 51). Infantry from the estates of Komnenos, Kekaumenos, and other rebels, was complemented by the troops of the Varangians and Armenians. They were an important supplement because we can classify them as heavy infantry. Similarly, the two formations of Latins (Franks) who, as a heavy cavalry, completed the horse riders of the usurper and his supporters. To all this, Isaac had a network of spies who reported him about the enemy's movements, and above all about his army's morale.

Komnenos did not hurry to fratricide the army of the Romans from Anatolia, faithful to Michael VI. This is best demonstrated by his slow march towards Nicaea. This allowed for the sowing of doubt in military units faithful to the old Emperor, which translated into the desertions of ordinary soldiers, and probably also some of their commanders. Thanks to such a considerate handling of his countrymen, Nicaea fell into Komnenos's hands smoothly. However, in the case of an army coming from the western part of the country, of which the Macedonians were an important part, Isaac did not have such scruples anymore. The Battle of Petroe was a bloody clash in which Aaron, his brother-in-law and commander of a part of the loyalist forces, stood against him. We do not know the number of soldiers faithful to Michael VI killed, because the data provided by Matthew of Edessa $(115,000$ deaths) cannot be taken as credible. Undoubtedly, the battle of Petroe deprived Michael VI of the military base and all military reserves from European provinces. And consequently, this defeat allowed his opponents in the capital to lift their heads. He had many opponents there, whose number also grew from the time he was an imperial official. Consequently, it only took 10 days after the battle to force him to resign and hand over the capital to Komnenos without any further bloodshed.

The attitudes and actions of Isaac Komnenos at the beginning of the rebellion cannot be unequivocally assessed. It is also difficult to say that his skills were decisive for the success during the battle of Petroe, since he had a moment of breakdown, during which he wanted to leave his army and hide behind the walls of nearby Nicaea. He had a cunctator attitude and faith in the good omens. These qualities also do not reflect well on him. And yet he managed to become an emperor, engaging in a political game with the envoys of Michael VI and dragged them to his side (especially Psellos). In this way, Isaac Komnenos cleared a path for people from his milieu to the imperial crown. It is true that his immediate successors were not his brother, but a representative of the Doukas family, but this did not change the balance of power, because the military aristocracy had mastered the power in the state for good(Bonarek 2011:48). Only after twenty-two years and a short reign associated with Isaac Nikephoros Botaneiates, did the power return to the Komnenos family, which went on to rule Byzantium for the next 100 years.

\section{References}

Mokhov A. S. 2012. Voyennaya politika Isaaka I Komnina // Nauchnyye vedomosti Belgorodskogo gosudarstvennogo universiteta. Ser., Istoriya. Ekonomika. Politologiya. Informatika. - Belgorod, 120: 52-60 (in Russian). Nicephore Bryennios Histoire. 1975. Corpus Fontium Historiae Byzantinae, v. 9, P. Gautier(ed.), Brussels.

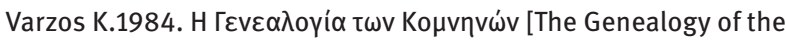
Komneno, v. A. Thessaloniki: Centre for Byzantine Studies, University of Thessaloniki (in Greek).

Ioannis Skylitzae.1973. Synopsis Historiarum, I. Thurn (ed.), BerlinNew York. 
Nezu Y.2006. The Revolt of Isaakios Komnenos: Reconsideration, J. Orient, 42: 41-60.

Michael Psellos, Chronographie (976-1077). 1928. t. I - II, E. Renauld (ed.), Paris.

Michael Attaliates, The History. 2012. A. Kaldellis, D. Krallis(transl. and ed.), London.

Hussey J.1935. Michael Psellos, the Byzantine Historian, J. Speculum, 10: 81-83.

Polemis D.I. 1965. When Did Psellos Die ?, J. Byzantinische Zeitschrift, 58: 73-75.

1)urewicz 0. 1984.,,Die Chronographie” des Michael Psellos als Quelle zur byzantinischen Kultur im Ausgang des $10 \mathrm{Jh} .$, J. Eos, 72/2: 315-322 (in German).

Domaradzki K.2005. Kariera polityczna Michata Psellosa na dworze bizantyńskim w XI w., Acta Universitatis Lodziensis. Folia Historia, 80: 117-138 (in Polish).

Krallis D.2012., Michael Attaleiates and the Politics of Imperial Decline in Eleventh Century Byzantium Tempe: Arizona Center for Medieval and Renaissance Studies.

Krallis D. 2009.,Democratic Action in Eleventh-Century Byzantium: Michael Attaleiates Republicanism in Context, J. Viator, 40.2: 35-53

Krallis D. 2009. Sacred Emperor, Holy Patriarch: A New Reading of the Clash between Emperor Isaakios I Komnenos and Patriarch Michael Keroularios in Attaleiates' History, J. Byzantinoslavica, 67: 169-190.

Krallis D. 2006. Michael Attaleiates as a Reader of Psellos, in Ch. Barber (ed.), Reading Michael Psellos Leiden: 167-191.

Seibt W.1976. Johannes Skylitzes: Zur Person des Chronisten, J. Jahrbuch der österreichischen Byzantinistik, 25: 81-85 (in German).

Inoue K.1993. The Rebellion of Isaakios Komnenos and the Provincial Aristocratic Oikoi, J. Byzantinoslavica, 54: 268-278.

Bonarek J.2011. Bizancjum w dobie bitwy pod Mantzikert, Kraków, (in Polish).

Dudek J.2009. Pęknięte zwierciadło-kryzys i odbudowa wizerunku władcy bizantyńskiego od 1056 do ok. 1095 roku, Zielona Góra,(in Polish).

Angold M.1984. The Byzantine Empire 1025-1204. A political history, London, 1984.

Krsmanović B.2001. Uspon vojnog plemstva u Vizantii XI veka,Beograd,(in Serbian).

Mochov A.S.2003. Komandnyi sostaw vizantijskoi armii v 1055-1057 gg, Antičnaia Drevnost' i Srednie Veka, 2002, 33: 109-122 (in Russian).

Constantini Manassis Breviarium chronicum.1996. 2 vols. 0. Lampsidis (ed.) Athens.

Ioannis Zonarae Epitome Historiarum libri XIII-XVIII.1897. Corpus scriptorum historiae Byzantinae 49, T. Büttner-Wobst (ed.), Leipzig.

The Chronik of Matthew of Edessa. 1993. A.E. Dostourian (ed.), New York.

Shepard J.1977. Isaac Comnenus Coronation Day, J. Byzantinoslavica, 38: 22-30.

Treadgold W. T.1997. A History of the Byzantine State and Society. Stanford.

Kaldellis A.2017., Streams of Gold, Rivers of Blood: The Rise and Fall of Byzantium, 955 A.D. to the First Crusade. New York. 